\title{
Dietary Effects of Post-fermented Green Tea by Monascus pilosus on the Body Weight, Serum Lipid Profiles and the Activities of Hepatic Antioxidative Enzymes in Mouse Fed a High Fat Diet
}

\author{
Sang-Il Lee $\cdot$ Ye-Kyung Lee $\cdot$ Soon-Dong Kim $\cdot$ Seung Hwan Yang $\cdot$ Joo-Won Suh
}

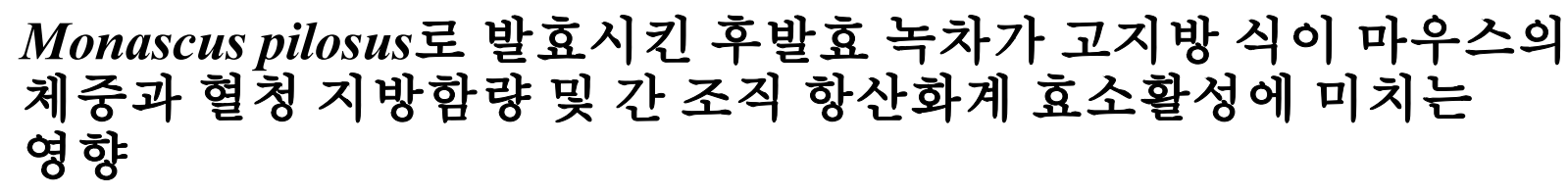

이상일 · 이예경 · 김순동 · 양숭환 · 서주원

Received: 14 January 2012 / Accepted: 12 April 2012 / Published Online: 30 June 2012

(C) The Korean Society for Applied Biological Chemistry 2012

\begin{abstract}
The anti-obese, hypolipidemic and hepatoprotective effects of post-fermented green tea by Monascus pilosus was tested with mice fed with high-fat diet for 7 weeks. The body weight gain and feed efficiency ratio (FER) in normal control group (NC), CHA ( $2 \%$ non-fermented green tea powder supplemented high-fat diet group) and mCHA (2\% green tea powder post-fermented by $M$. pilosus supplemented high fat diet group) groups were significantly lower than those of high fat diet control group (HC). Epididymal fat weight in mCHA and $\mathrm{NC}$ were significantly lower than $\mathrm{HC}$. The hepatic lipid peroxide was dramatically higher in $\mathrm{HC}$ than that of $\mathrm{NC}$ and was significantly lower in CHA and mCHA. In addition, dehydrogenase type activity of xanthine oxidoreductase in $\mathrm{HC}$ was lower than that of $\mathrm{NC}$, but significantly higher than $\mathrm{CHA}$ and mCHA. In histopathological findings, hepatic fat accumulation in $\mathrm{HC}$ was higher than that of $\mathrm{NC}, \mathrm{CHA}$ and mCHA. Antiobese, hypolipidemic and antifatty liver effect of green tea powder post-
\end{abstract}

J. W. Suh and S. H. Yang contributed equally.

Y.-K. Lee $\cdot$ S.-D. Kim $\cdot$ S. H. Yang $(\bowtie) \cdot J .-W . S u h(\bowtie)$

Division of Bioscience and Bioinformatics, College of Natural Science, Myongji University, Cheoin-gu, Yongin, Gyeonggi-Do 449-728, Republic of Korea

E-mail: jwsuh@mju.ac.kr(J.-W. Suh)

E-mail:ymichigan@mju.ac.kr(S.H. Yang)

S.-I. Lee

Department of Food, Nutrition and Cookery, Keimyung College, Daegu 704-703, Republic of Korea fermented by $M$. pilosus was slightly higher than that of nonfermented green tea. In conclusion, the constituents of green tea fermented by $M$. pilosus has been proven to not only inhibit obesity and hyperlipidemia but also decrease the hepatic fat accumulation in high fat diet-induced obese mice.

Keywords anti-fatty liver - antiobese - antioxidative enzymes · hypolipidemic $\cdot$ Monascus pilosus $\cdot$ post-fermented tea

\section{서 론}

차는 전 세계인이 즐겨 마시는 가장 보편적인 음료로 비발효차, 반발효차, 발효차, 후발효차 등으로 분류하고 있으며, 전 세계 적으로 녹차(비발효차) $20 \%$, 오룡차(반발효차) $2 \%$, 흑차(발효 차) $78 \%$ 가 소비되고 있다(Bode와 Dong, 2003). 우리나라에서 는 신라 선덕여왕(AD 632 647) 때 중국 당나라에서 차를 가져 와 마셨으며, $\mathrm{AD}$ 828년에 지리산에 차를 재배하였다(Lee, 1984; Kim, 1989). 흑차의 발효는 phytoenzyme에 의한 것과 외부의 효소나 미생물을 사용하여 발효시키는 것으로 나누며 홍차는 전 자에 중국 운남성의 보이차는 후자에 포함된다. 흑차는 주로 미 국, 영국 및 유럽국가에서 애용하고 있으며 녹차는 아시아 북 아프리카 국가들에서 그리고 오룡차는 중국과 타이완에서 많이 이용하고 하고 있다(Trevisanato와 Kim, 2000). 녹차의 주요 기 능성 성분인 catechin류는 발효과정 중에 theaflavins (TF)과 thearubigins (TG)로 전환된다. Catechin류에는 (-)-epigallocatechin3-gallate (EGCG)의 함량이 가장 높고, 다음으로 (-)-epigallocatechin 
(EGC)과 (-)-epicatechin (EC)이 함유되어 있다. 또한 흑차의 polyphenol로 알려진 theaflavins로는 theaflavin-3-gallate와 theaflavin-3,3'-digallate가 있으며 흑차의 색상과 맛에 영향을 주 는 물질로 알려져 있다(Yang 등, 2000). 녹차나 흑차에 함유된 이러한 성분들은 모두 강한 항산화능을 지님으로써 체내 산화 적 스트레스의 해소를 통하여 각종 생활 습관병의 예방과 치유 에 관여한다(Lin 등, 1999).

흑차는 총 항산화능에서는 녹차에 비하여 낮으나(Han 등, 2010), 발효 중에 새로이 생성된 TF 및 TG가 $\mathrm{H}_{2} \mathrm{O}_{2}$ 와 $\mathrm{t}-$ butylhydroperoxide로 유도한 세포독성과 산화적 스트레스를 감 소시키며(Feng 등, 2002), 항돌연변이 효과가 녹차의 EGCG에 비하여 현저하게 높은 것으로 알려져 있다(Chen 등, 1999; Liang 등, 1999).

Monascus속 미생물은 항균 및 항암효과(Birch 등, 1962)가 있는 rubropuntain 및 monascin과 같은 성분을 생성(Pyo와 Lee, 2007)할 뿐만 아니라 체내 콜레스테롤의 생합성을 저해하 는 monacolin $\mathrm{K}$, mevinolin, lovastatin과 같은 statin계 성분을 생성한다(Endo, 1980). 또한, Monascus속 미생물의 균체는 항 비만 효과가 알려져 있으며(Lee 등, 2011a), 비만에서 오는 간 손상을 해소시키는 것으로 보고되어 있다(Lee 등, 2011b).

본 연구에서는 발효차의 품질개선과 기능성 부여를 위한 일 련의 연구로 M. pilous로 발효시킨 후발효 녹차가 고지방 식이 마우스의 체중과 혈청 지방함량 및 간 조직 항산화계 효소활성 에 미치는 영향을 조사하였다.

\section{재료 및 방법}

재료 및 균주. 실험에 사용한 녹차(Aspalathus linearis)는 2011 년 4월에 경상남도 하동군에서 첫물(1지2엽)을 채취하여 사용 하였으며, 균주는 한국종균협회에서 분양 받은 M. pilosus $\mathrm{KCCM}$ 60084를 사용하였다.

차의 발효. 차의 발효는 재료 및 방법에서와 같이 채취한 녹차 잎을 하루 동안 위조시킨 다음 $250^{\circ} \mathrm{C}$ 의 덖음 솥에 넣어 덖음 과 유념을 5 회 반복하여 덖음차 $(\mathrm{CHA})$ 를 조제하였다. 이 덖음 차에 증류수를 가하여 $37.5 \%$ 수분함량으로 조정한 후 $2 \mathrm{~L}$ 들 이 polypropylene bag에 $500 \mathrm{~g}$ 씩 넣고 air filter를 부착한 후 $121^{\circ} \mathrm{C}$ 에서 90 분간 가압 살균하였다. 살균한 후는 무균상으로 옮 겨 실온이 되도록 식히고, 미리 준비한 M. pilosus 배양액 50 $\mathrm{mL}$ 씩을 혼합하여 $30^{\circ} \mathrm{C}$ 의 incubator에서 15 일간 배양하여 발효 차 $(\mathrm{mCHA})$ 를 제조하였다. 발효가 끝난 차는 $40^{\circ} \mathrm{C}$ 에서 최종 수 분함량이 $2 \%$ 내외가 되도록 충분히 건조시켜 실험에 사용하였다.

M. pilosus 배양액은 5\% glucose, $2 \%$ peptone, $0.8 \% \mathrm{KH}_{2} \mathrm{PO}_{4}$, $0.05 \% \mathrm{MgSO}_{4} \cdot 7 \mathrm{H}_{2} \mathrm{O}, 0.2 \% \mathrm{CH}_{3} \mathrm{COOK}, 0.1 \% \mathrm{NaCl}$ 를 함유하 는 액에 균주를 접종하여 $150 \mathrm{rpm}$ 의 진탕 배양기에서 10 일간 배양하여 사용하였다.

동물실험. 실험동물은 4주령의 평균체중 $21 \pm 5 \mathrm{~g}$ 의 ICR (Crljori: CD-1), SPF/VAF outbred mice (Orient Ltd, Korea)를 기본사 료인 5L79 diets (PMI Nutrition, USA)로 1주일간 사육하여 환경에 적응시킨 다음 실험에 사용하였다. 실험군은 기본사료만 을 급여한 정상군(normal control group, $\mathrm{NC}$ ), 기본사료에 lard 를 $37.5 \%(\mathrm{w} / \mathrm{w})$ 혼합한 고지방식이 대조군(high fat diet control group, HC), 기본사료에 lard $37.5 \%$ (w/w)와 비발효 녹차를 $2 \%$ 혼합한 식이군(CHA) 및 기본사료에 $\operatorname{lard} 37.5 \%$
Table 1 Experimental plots and diet compositions (\%)

\begin{tabular}{lcccc}
\hline \multirow{2}{*}{ Ingredients } & \multicolumn{4}{c}{ Experimental plots ${ }^{1)}$} \\
\cline { 2 - 5 } & $\mathrm{NC}$ & $\mathrm{HC}$ & $\mathrm{CHA}$ & $\mathrm{mCHA}$ \\
\hline Pellet stew (5L79 diets) ${ }^{2)}$ & 100 & 62.5 & 60.5 & 60.5 \\
Lard & - & 37.5 & 37.5 & 37.5 \\
Unfermented green tea powder & - & - & 2.0 & - \\
Post-fermented green tea powder & - & - & - & 2.0 \\
\hline
\end{tabular}

${ }^{1)}$ Abbreviations: $\mathrm{NC}$; normal control group, $\mathrm{HC}$; high fat control group, CHA; unfermented green tea powder $2 \%$ supplemented high fat diet group, mCHA; post-fermented green tea powder by M. pilosus $2 \%$ supplemented high fat diet group.

${ }^{2)}$ The diets for animal experiments manufactured in the PMI Nutrition, USA. Guaranteed analysis: crude protein $18 \%$, crude fat $5 \%$, crude fiber $5 \%$, ash $8 \%$.

(w/w)와 M. pilosus로 후발효시킨 발효차를 $2 \%$ 혼합한 식이군 (mCHA)의 4 개군(6마리/군)으로 구분하여 7 주간 사육하였다 (Table 1).

실험식이는 1 주일에 한 번씩 제조하여 $4^{\circ} \mathrm{C}$ 에서 보관하면서 매일 신선한 식이를 공급하였다. 사육장은 stainless steel cage 를 사용하였고, 온도 및 습도는 $23 \pm 2^{\circ} \mathrm{C}, 60 \pm 5 \%$ 로 조정하였으 며, 명암주기는 12 시간 간격으로 설정하고, 물과 사료는 자유 섭취시켰다.

식이 섭취량, 체중 증가량 및 식이효율 측정. 체중과 식이섭취 량은 전 실험기간 동안 매일 일정시간에 측정하였으며, 식이효 율(feed efficiency ratio, FER)은 1주간의 체중증가량을 1주간의 식이섭취량으로 나눈 값으로 하였다.

혈청 지질함량. 혈청중성지질, 총콜레스테롤 및 high-density lipoprotein (HDL)-콜레스테롤 함량은 kit 시약(AM 157S-K, AM 202-K, AM 203-K, Asanpharm Co., Korea)으로 측정하 였으며, low-density lipoprotein (LDL)-콜레스테롤함량은 Friedewald 등(1972)의 방법에 따라 계산하였다.

Atherogenic index (AI)는 계산식(total cholesterol HDLcholesterol)/HDL-cholesterol에 의하여 산출하였다.

효소활성 측정 시료 준비. 7주간 사육한 mouse는 물만 주고 12 시간 동안 금식시킨 후 ether 마취하에서 복부 대동맥으로부터 채혈한 다음, 빙냉의 생리식염수로 간을 관류하고 장기를 적출 한 후 습기를 제거하고 무게를 측정하였다. 적출한 간 조직 일 정량에 4 배 량의 빙냉의 $0.25 \mathrm{M}$ sucrose 용액을 가하여 마쇄한 균 질액을 $10,000 \times \mathrm{g}$ 에서 30 분간 원심분리한 다음 post-mitochondrial fraction을 취해 효소 활성도 측정에 이용하였다. 채취한 혈액은 실온에서 응고시킨 다음 $4,2,500 \times \mathrm{g}$ 에서 20 분간 원심분리 하여 혈청을 분리한 후 $70^{\circ} \mathrm{C}$ 에 두면서 분석용 시료로 사용하였다.

혈청 ALT 활성의 측정. 혈청 alanine aminotransferase (ALT) 활성은 Reitman과 Franke 등(1979)의 방법에 따라 조제된 kit시 약(Asan Pham., Korea)을 사용하여 측정하였으며 효소의 활성 은 혈청 $1 \mathrm{~mL}$ 당 분당 $\mathrm{NADH}$ 의 흡광도를 0.001 감소시키는 Karmen unit로 나타내었다.

간 조직 $\mathrm{GSH}$ 및 $\mathrm{LPO}$ 의 함량 측정. 간 조직 glutathione $(\mathrm{GSH})$ 의 함량은 Ellman (1959)의 방법에 따라 일정량의 간 조 직 마쇄균질액에 5,5'-dithibis(2-nitrobenzoic acid)를 가하여 생 성되는 thiophenol의 흡광도를 측정하였으며 간 조직 $\mathrm{g}$ 당 환원 형 GSH $\mu$ mole로 나타내었다.

Lipid peroxide (LPO)의 함량은 Ohkawa 등(1979)의 방법에 
따라 일정량의 간 조직 마쇄균질액에 thiobarbituric acid (TBA) 용액을 가하여 반응시킨 후 $n$-butanol을 가하여 이행되는 TBAreactive substance를 흡광도 $532 \mathrm{~nm}$ 에서 측정한 다음 분자흡광 계수 $\left(\varepsilon=1.5 \times 10^{5} \mathrm{M}^{-1} \mathrm{~cm}^{-1}\right)$ 를 이용하여 함량을 산출하였으며 간 조직 $\mathrm{g}$ 당 malondialdehyde nmole로 나타내었다.

간 조직 xanthine oxidoreductase (XOR), superoxide dismutase (SOD), glutathione S-transferase (GST) 및 glutathione peroxidase (GPX) 활성 측정. XOR 활성은 Stirpe와 Della Corte (1969)의 방법에 따라 total type 활성은 $\mathrm{NAD}^{+}$의 존재 하 에서, $\mathrm{O}$ type 활성은 $\mathrm{NAD}^{+}$를 첨가하지 않은 상태에서 측정하 였으며 D type 활성은 total type 활성에서 $\mathrm{O}$ type 활성을 제한 값으로 산출하였다. 활성도는 분당 단백 $1 \mathrm{mg}$ 이 기질인 xanthine 으로부터 생성되는 uric acid의 량을 nmole로 나타내었다.

SOD 활성은 Martin 등(1987)의 방법에 따라 superoxide anion radical에 의해 hematoxylin으로부터 생성되는 hematin을 $560 \mathrm{~nm}$ 에서 측정하였으며 효소원을 가하지 않은 대조구의 흡광 도를 $50 \%$ 억제하는 효소량을 1 unit $(\mathrm{U})$ 로 하여 $1 \mathrm{mg}$ 의 단백 질이 hematoxylin의 자동산화를 억제하는 정도를 U로 나타내었 다. GST 활성은 Habig 등(1974)의 방법에 따라 효소에 의해 기질인 1-chloro-2,4-dinitrobezene과 reduced glutathione이 반응 하여 생성되는 thioether의 흡광도를 $340 \mathrm{~nm}$ 에서 측정한 다음 흡광계수 $\left(\varepsilon=9.5 \mathrm{M}^{-1} \mathrm{~cm}^{-1}\right)$ 를 이용하여 활성도를 계산하였으며 분당 단백질 $1 \mathrm{mg}$ 이 생성시킨 thioether의 nmole로 나타내었다.

GPX 활성은 Paglia와 Valentine (1967)의 방법에 따라 $1 \mathrm{mM}$ EDTA 함유하는 $50 \mathrm{mM}$ phosphate buffer (pH 7.0) 용액 일정 량에 $1 \mathrm{mM}$ sodium azide, $0.2 \mathrm{mM}$ NADPH, $1 \mathrm{mM}$ reduced glutathione, $1 \mathrm{U}$ glutathione reductase 및 일정량의 효소원과 기질 인 $0.25 \mathrm{mM}$ hydrogen peroxide를 가해 $25^{\circ} \mathrm{C}$ 에서 반응시키는 동 안에 생성된 oxidized glutathione을 환원시키는데 소모된 $\mathrm{NADPH}$ 를 $340 \mathrm{~nm}$ 에서 측정하고 분자흡광계수 $\left(\varepsilon=6.22 \mathrm{mM}^{-1} \mathrm{~cm}^{-1}\right)$ 를 이용 하여 효소활성을 계산하였다. 효소의 활성도는 $1 \mathrm{mg}$ 의 단백질이 1 분간 산화 시킨 NADPH의 함량을 nmole로 나타내었다.

단백질 측정. 간 조직의 단백질 함량은 Lowry 등(1951)의 방법 에 따라 bovine serum albumin (BSA)을 표준용액으로 하여 측정하였다.

간 조직 검사. 7주간 사육한 흰쥐 간 조직을 절취하여 $10 \%$ neutral formalin에 고정시킨 다음, 알코올 탈수, 파라핀 포매하 여 microtome으로 $4 \mu \mathrm{m}$ 두께로 잘라 hematoxylin과 eosin으로 염색하여 광학현미경으로 관찰하였다.

통계 처리. 데이터는 실험동물 6마리에 대한 평균치와 표준편
차로 나타내었다. 유의성 검증은 SPSS ver. 14.0 (SPSS Inc., USA) software package program을 이용하여 Duncan's multiple range test를 행하였다.

\section{결과 및 고찰}

체중변화. 정상군 $(\mathrm{NC})$, 고지방 식이 대조군 $(\mathrm{HC})$, 녹차분말 $2 \%$ 를 혼합한 고지방식이군(CHA) 및 M. pilosus로 발효시킨 후발 효 녹차 분말을 $2 \%$ 혼합한 고지방식이군 $(\mathrm{mCHA})$ 의 4 개군으로 구분하여 7주간 사육하면서 조사한 누적체중증가량과 주당 체 중증가량 및 식이섭취량을 조사한 결과는 Table 2 와 같다.

실험식이 개시일의 평균체중은 $26.88 \sim 28.65 \mathrm{~g}$ 으로 유의적인 차이를 보이지 않았으나 7주후의 체중은 $\mathrm{NC}$ 군의 증가율에 비 하여 $\mathrm{HC}$ 군의 증가율은 $48.68 \%$ 가 높았으며, $\mathrm{CHA}$ 는 $26.04 \%$, $\mathrm{mCHA}$ 는 $21.10 \%$ 가 증가하였다(Table 2). 즉, $\mathrm{CHA}$ 와 $\mathrm{mCHA}$ 군 은 상호간의 유의적인 차이는 없으나 $\mathrm{HC}$ 군에 비하여 각각 24.15 및 $29.66 \%$ 의 체중감소가 있었다(Table 2). 한편, 칼로리 섭취량은 $\mathrm{NC}$ 군에 비해 $\mathrm{HC}$ 군에서 $33.02 \%$ 가 증가하였으며, 또 한 $\mathrm{CHA}$ 와 $\mathrm{mCHA}$ 군에서는 $\mathrm{HC}$ 군에 비해 각각 11.70 및 $11.52 \%$ 가 증가하였다(Table 2). 그리고 물 섭취량은 $\mathrm{NC}$ 군에 비 해 $\mathrm{HC}$ 군에서 $19.63 \%$ 가 감소하였으나, $\mathrm{CHA}$ 군에서는 $\mathrm{HC}$ 군에 비해 증가하는 경향을 나타내었으며, $\mathrm{mCHA}$ 군에서는 대조군 수 준으로 회복되었다(Table 2).

이상의 결과에서 보이듯이 $\mathrm{CHA}$ 및 $\mathrm{mCHA}$ 군에서 식이섭취 량과 칼로리 섭취량이 $\mathrm{HC}$ 군에 비해 유의하게 증가하였으나 증 체량은 감소하는 것으로 보아 $\mathrm{CHA}$ 및 $\mathrm{mCHA}$ 군 모두 뚜렷한 체중조절효과가 있는 것으로 판단된다. 또한 $\mathrm{CHA}$ 및 $\mathrm{mCHA}$ 군의 식이효율도 $\mathrm{NC}$ 군보다는 높으나 $\mathrm{HC}$ 군에 비하여는 유의적 으로 낮았다.

고지방식이에서 식이섭취량이 감소하는 현상은 Lee 등(1998) 의 결과와 일치하며 $\mathrm{CHA}$ 군에서 체중감소효과를 보이는 현상 은 녹차에 함유된 polyphenol성분에 기인된 것으로 사료되며 $\mathrm{mCHA}$ 에서의 효과는 polyphenol 성분과 함께 Monascus속 미 생물이 발효 중에 생성된 생성물(Yu 등, 2005) 또는 균체가 가 지는 효과(Lee 등, 2011a)에 기인된 것이라 생각된다.

장기중량과 부고환주변지방의 함량. 7주간 사육한 실험동물의 장기중량과 부고환주변지방의 함량을 조사한 결과는 Table 3과 같다. 체중에 대한 간 중량은 $\mathrm{NC}$ 군 $3.88 \%, \mathrm{HC}$ 군 $3.26 \%$, $\mathrm{CHA} 3.39 \%, \mathrm{mCHA} 3.47 \%$ 로 $\mathrm{HC}$ 군에 가장 낮았으며 체중 증

Table 2 Weight gain and feed efficiency ratio of mouse fed with high fat diets for 7 weeks

\begin{tabular}{|c|c|c|c|c|}
\hline \multirow{2}{*}{ Measurements } & \multicolumn{4}{|c|}{ Experimental plots ${ }^{1)}$} \\
\hline & $\mathrm{NC}$ & $\mathrm{HC}$ & CHA & $\mathrm{mCHA}$ \\
\hline Initial weight (g) & $26.88 \pm 1.93^{\mathrm{NS}, 3)}$ & $28.58 \pm 1.39$ & $28.65 \pm 1.40$ & $28.52 \pm 1.34$ \\
\hline Final weight $(\mathrm{g})$ & $38.88 \pm 4.51^{\mathrm{c}}$ & $55.25 \pm 3.75^{\mathrm{a}}$ & $48.90 \pm 4.08^{\mathrm{ab}}$ & $47.27 \pm 4.32^{\mathrm{bc}}$ \\
\hline Weight gain (g/week) & $1.71 \pm 0.20^{\mathrm{c}}$ & $3.81 \pm 0.26^{\mathrm{a}}$ & $2.89 \pm 0.25^{\mathrm{b}}$ & $2.68 \pm 0.27^{\mathrm{b}}$ \\
\hline Water intakes (mL/week) & $27.76 \pm 1.22^{\mathrm{a}}$ & $22.31 \pm 1.35^{\mathrm{c}}$ & $24.65 \pm 1.55^{\mathrm{bc}}$ & $27.34 \pm 1.48^{\mathrm{ab}}$ \\
\hline Feed intakes (g/week) & $31.63 \pm 0.95^{\mathrm{a}}$ & $27.38 \pm 0.99^{b}$ & $30.20 \pm 1.18^{\mathrm{a}}$ & $30.17 \pm 0.98^{\mathrm{a}}$ \\
\hline Calory intakes (kcal/week) & $117.97 \pm 3.54^{\mathrm{c}}$ & $156.92 \pm 5.27^{\mathrm{b}}$ & $175.28 \pm 6.85^{\mathrm{a}}$ & $174.99 \pm 5.68^{\mathrm{a}}$ \\
\hline $\mathrm{FER}^{2)}$ & $0.05 \pm 0.01^{\mathrm{c}}$ & $0.14 \pm 0.01^{\mathrm{a}}$ & $0.10 \pm 0.01^{\mathrm{b}}$ & $0.09 \pm 0.01^{\mathrm{b}}$ \\
\hline
\end{tabular}

\footnotetext{
${ }^{1)}$ See Table 1.
}

${ }^{2)}$ Feed efficiency ratio.

${ }^{3)} \mathrm{NS}$ : Not significant. Values are mean $\pm \mathrm{SD}$, different superscripts in the same row indicate (a-c) significant differences $(p<0.05)$. 
Table 3 Effects of unfermented and post-fermented green tea by M. pilosus on the weight of organs and content of fat around epididymal in mouse fed height fat diets for 7 weeks

(\% against body weight)

\begin{tabular}{lllll}
\hline \multirow{2}{*}{ Organs } & \multicolumn{4}{c}{ Experimental groups $^{1)}$} \\
\cline { 2 - 5 } & \multicolumn{1}{c}{$\mathrm{NC}$} & $\mathrm{HC}$ & \multicolumn{1}{c}{ CHA } & mCHA \\
\hline Liver & $3.88 \pm 0.24^{\mathrm{a}, 2)}$ & $3.26 \pm 0.25^{\mathrm{b}}$ & $3.39 \pm 0.20^{\mathrm{b}}$ & $3.47 \pm 0.19^{\mathrm{b}}$ \\
Kidney & $1.41 \pm 0.18^{\mathrm{a}}$ & $1.03 \pm 0.20^{\mathrm{b}}$ & $1.14 \pm 0.20^{\mathrm{ab}}$ & $1.17 \pm 0.19^{\mathrm{ab}}$ \\
Heart & $0.48 \pm 0.07^{\mathrm{NS}, 3)}$ & $0.39 \pm 0.11$ & $0.40 \pm 0.09$ & $0.43 \pm 0.08$ \\
Fat around epididymal & $2.39 \pm 0.65^{\mathrm{c}}$ & $5.79 \pm 0.53^{\mathrm{a}}$ & $5.24 \pm 0.96^{\mathrm{ab}}$ & $4.73 \pm 0.56^{\mathrm{b}}$ \\
\hline
\end{tabular}

${ }^{1)}$ See Table 1.

${ }^{2}$ Values are mean $\pm \mathrm{SD}(\mathrm{n}=6)$, different superscripts in the same row indicate (a-c) significant difference $(p<0.05)$.

${ }^{3)}$ Not significant.

가율이 낮을수록 높아지는 경향을 보였으며 신장과 심장에서도 간에서와 동일한 경향을 나타내었으나 심장에서는 유의적인 차 이는 보이지 않았다(Table 3). 특히 간에서 나타난 이러한 현상 은 고지방식이에서의 간 비대현상이 체중 증가율이 미치지 못 하기 때문에 나타난 현상으로 Matsuzawa-Nagatan 등(2008) 및 $\mathrm{Ha}$ 와 $\mathrm{Chae}(2010)$ 의 보고와 일치하였다. 고지방식이에서는 불균 형한 당대사와 이로인해 생성된 과잉의 glucose flux 및 비정상 적인 $\mathrm{RNA}$ 와 $\mathrm{DNA}$ 의 합성 등으로 장기조직이 비대해지는 것으 로 알려져 있다(Wu 등, 2007).

부고환주변지방의 함량은 $\mathrm{HC}$ 군에서는 $\mathrm{NC}$ 군의 2.42 배에 달 하였으나 $\mathrm{CHA}$ 군과 $\mathrm{mCHA}$ 군에서는 $\mathrm{HC}$ 군 보다 각각 9.50 및 $18.31 \%$ 가 낮았다(Table 3).

혈청지질 함량. 7 주간 사육한 실험동물의 혈청 triglyceride, total cholesterol, HDL-cholesterol 및 LDL-cholesterol 함량을 측정한 결과는 Fig. 2과 같다. Triglyceride 함량은 $\mathrm{CHA}$ 군과 $\mathrm{mCHA}$ 군 간에는 유의적인 차이를 보이지 않았으나 $\mathrm{mCHA}$ 군은 $\mathrm{HC}$ 군에 비하여 유의적으로 낮은 함량을 나타내었으며 $\mathrm{NC}$ 군과 비슷한 값을 나타내었다(Fig. 1A).

Total cholesterol 함량도 triglyceride 함량과 유사한 경향으로 $\mathrm{CHA}$ 군은 $\mathrm{HC}$ 군과의 유의차를 보이지 않으나 $\mathrm{mCHA}$ 는 $\mathrm{HC}$ 군 에 비하여 $12.48 \%$ 가 낮았으며 $\mathrm{NC}$ 군의 수준을 나타내었다(Fig. 1B).

HDL-cholesterol 함량은 $\mathrm{HC}$ 군이 $35.40 \mathrm{mg} / \mathrm{dL}$ 로 $\mathrm{NC}$ 군 68.73 $\mathrm{mg} / \mathrm{dL}$ 의 $51.5 \%$ 에 불과하였으나 $\mathrm{CHA}$ 군과 $\mathrm{mCHA}$ 군은 각각 69.58 및 $77.64 \mathrm{mg} / \mathrm{dL}$ 로 $\mathrm{HC}$ 군에 비하여 96.55 및 $119.32 \%$ 가 높았다(Fig. 1C). 그러나 LDL-cholesterol 함량은 $\mathrm{CHA}$ 군 및 $\mathrm{mCHA}$ 군이 각각 24.04 및 $10.22 \mathrm{mg} / \mathrm{dL}$ 로 $\mathrm{NC}$ 군의 $17.59 \mathrm{mg} /$ $\mathrm{dL}$ 과 유사한 값을 나타내었으며 $\mathrm{HC}$ 군의 $60.00 \mathrm{mg} / \mathrm{dL}$ 보다 현저 히 낮은 값을 나타내었다(Fig. 1D). 동맥경화지수는 $\mathrm{HC}$ 군이 2.47을 나타낸 반면, $\mathrm{CHA}$ 군 및 $\mathrm{mCHA}$ 군은 각각 0.67 및 0.41 을 나타내어 $\mathrm{NC}$ 군과 유의적인 차이를 보이지 않았다(Fig. 1E). 일반적으로 고지방식이에서는 혈중 chylomicron의 함량이 증가 하여 very low density lipoprotein (VLDL)과 LDL의 함량 높 인다(Wilson 등, 1984). 따라서 고지방 식이는 동맥경화성 관상 동맥질환과 뇌혈관질환의 발생률을 높임(Lee 등, 2003)과 동시 에 합병증의 유발을 촉진(Gordon 등, 1981)하나 HDL은 LDL 의 생성을 억제 또는 cholesterol 함량을 감소시킴으로서 동맥경 화를 억제한다(Park 등, 2006).

녹차에서 혈청지질의 개선효과를 보이는 것은 녹차에 함유된 다양한 항산화성 물질의 효과라 사료되며 Monascus속 미생물 에 의한 후발효 녹차에서 나타난 상기의 효과는 녹차에 함유된 성분들과 함께 발효 중에 생성된 monacolin $\mathrm{K}$ 를 비롯한 성분
들에 의한 영향이라 사료된다. Heber 등(1999)은 Monascus속 미생물의 대사산물인 monacolin K가 혈중 total cholesterol, LDL-cholesterol 및 triglycerol 농도를 감소시키는 효과가 있다 고 하였으며, Arad 등(1990)은 고콜레스테롤혈증 환자에서는 LDL-cholesterol함량을 우선적으로 낮추나 정상인에서는 VLDL 과 $\mathrm{LDL}$ 의 생성을 동시에 낮춘다고 하였다.

이상의 실험결과 Monascus속 미생물로 발효시킨 후발효 녹 차는 고지방 식이로 유발될 수 있는 혈청지질의 함량을 개선함 과 동시에 동맥경화와 같은 생활습관병을 개선시키는 효과가 있 는 것으로 사료된다.

간 조직의 GSH 및 LPO 함량. 7주간 사육한 실험동물의 간 조직 $\mathrm{GSH}$ 및 $\mathrm{LPO}$ 의 함량을 측정한 결과는 Fig. 3와 같다. $\mathrm{GSH}$ 함량 $(\mu \mathrm{mole} / \mathrm{g}$ tissue)은 $\mathrm{HC}$ 군이 1.90 으로 $\mathrm{NC}$ 군의 2.94 에 비하여 $35.37 \%$ 가 낮았으며 $\mathrm{CHA}$ 군과 $\mathrm{mCHA}$ 군은 각각 2.09 및 2.35 로 유의적인 차이는 없으나 $\mathrm{mCHA}$ 군에서 $12.44 \%$ 가 높았으 며 $\mathrm{HC}$ 군에 비하여는 $23.68 \%$ 가 높았다(Fig. 2A). LPO 함량은 $\mathrm{NC}$ 군에 비하여 $\mathrm{HC}$ 군이 $54.34 \%$ 가 높았으나 $\mathrm{CHA}$ 군과 $\mathrm{mCHA}$ 군은 $\mathrm{HC}$ 군에 비하여 43.70 및 $45.38 \%$ 가 낮았으며 $\mathrm{NC}$ 군과의 유의적인 차이를 보이지 않았다(Fig. 2B).

간 조직 $\mathrm{GSH}$ 는 생성된 체내에서 생성된 활성산소종(ROS)을 소거시키는데 관여하며 $\mathrm{LPO}$ 의 생성을 막음으로써 $\mathrm{GSH}$ 함량이 감소하면 LPO 함량이 증가한다(Wang 등, 2000). 특히, GSH는 체내에서 생성된 $\mathrm{H}_{2} \mathrm{O}_{2}$ 를 소거하는 항산화제로 산화적 스트레스 에 대한 방어계의 기질로 이용된다(Kang 등, 2004). 그러나 $\mathrm{LPO}$ 는 산화적 스트레스에 의해 세포막이 손상되었을 때 증가 한다(Vladislav 등, 2004).

$\mathrm{ROS}$ 는 다가불포화지방산에 작용하여 $\mathrm{LPO}$ 를 생성하며 생성 된 $\mathrm{LPO}$ 는 분해되어 새로운 $\mathrm{ROS}$ 를 생성하거나 aldehyde, ketone, alcohol류 등을 생성하여 체내 세포조직을 손상케 하거 나 노화에 관여함으로 $\mathrm{LPO}$ 는 생체막의 손상 정도를 나타내는 지표로 알려져 있으며, xanthine oxidoreductase (XOD) O type 효소가 생성한 $\mathrm{ROS}$ 에 의하여 전환된 $\mathrm{LPO}$ 는 생체막 손상에 관 여 한다(Ohkawa 등, 1979).

따라서 녹차 또는 Monascus속 미생물로 발효시킨 후발효 녹 차는 고지방식이에서 체중을 감소시키는 효과를 나타냄과 동시 에 $\mathrm{GSH}$ 의 함량을 높이고 $\mathrm{LPO}$ 의 함량을 감소시킴으로써 간 손 상을 예방하는 효과가 있는 것으로 사료된다.

간 조직의 XOR의 활성. 7주간 사육한 실험동물의 간 조직 XOD D type 및 O type 효소의 활성(nmole/mg protein/ min: $\mathrm{U}$ )을 측정한 결과는 $\mathrm{Fig}$. 4와 같다. $\mathrm{CHA}$ 군과 $\mathrm{mCHA}$ 군의 $\mathrm{D}$ type 효소활성은 $\mathrm{HC}$ 군에 비하여 각각 18.52 및 $33.33 \%$ 가 감소 하였으나 $\mathrm{mCHA}$ 군은 $\mathrm{NC}$ 군과의 차이를 보이지 않았다(Fig. 

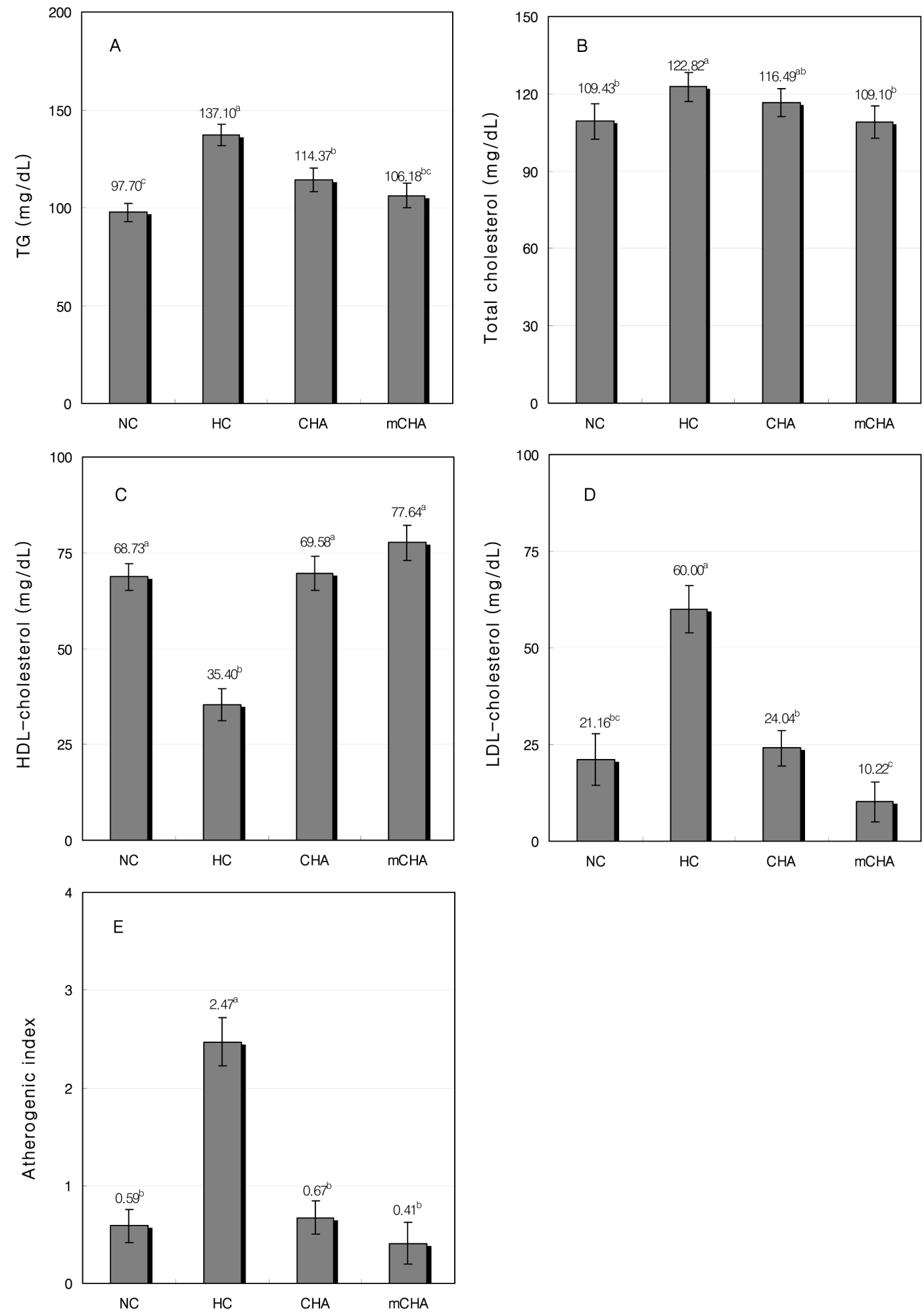

Fig. 1 Effects of unfermented and post-fermented green tea by M. pilosus on the content of triglyceride (TG) (A), total cholesterol (B), HDLcholesterol (C) and LDL-cholesterol (D) of in serum, and atherogenic index (E) of the mouse fed high fat diets for 7 weeks. Values are mean \pm SD $(\mathrm{n}=6)$, different superscripts on the bars indicate significant difference $(p<0.05)$.

3A). 그러나 $\mathrm{O}$ type 효소활성은 $\mathrm{HC}$ 군이 $\mathrm{NC}$ 군에 비하여 $30.43 \%$ 가 높았으며 $\mathrm{CHA}$ 군과 $\mathrm{mCHA}$ 군에서는 $\mathrm{HC}$ 군에 비하여
16.67 및 $33.33 \%$ 가 높았다(Fig. 3B).

$\mathrm{XOD}$ 는 hypoxanthine을 산화하여 uric acid를 생성하며 

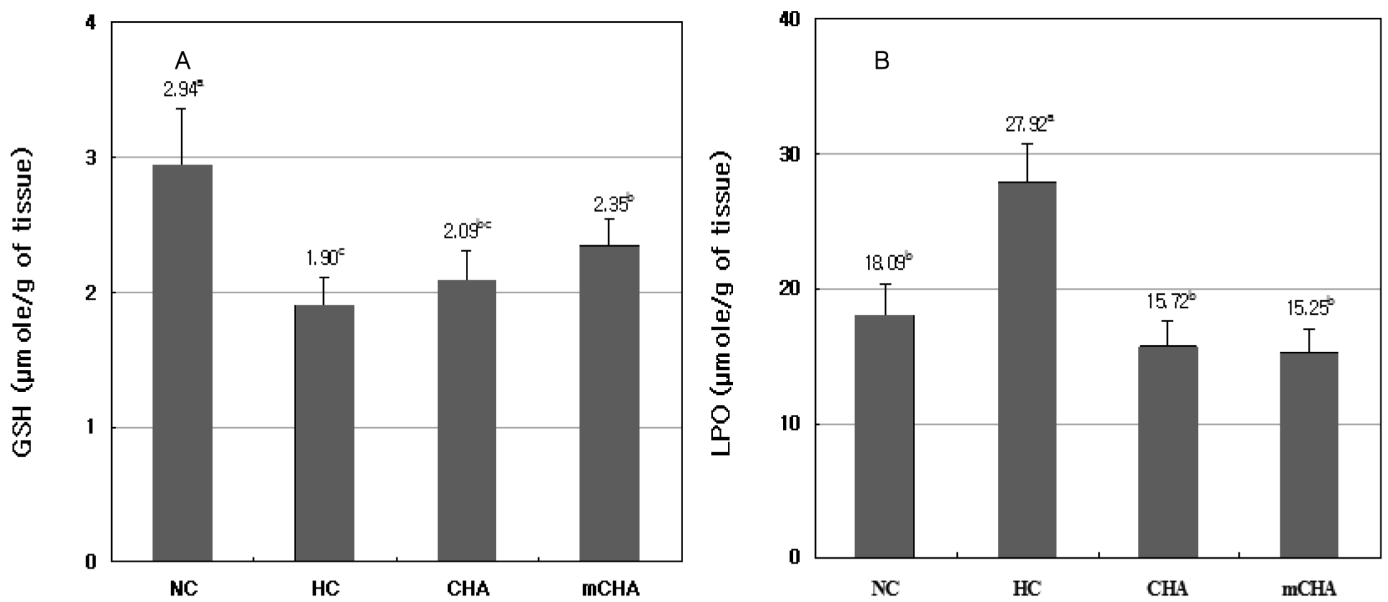

Fig. 2 Effects of unfermented and post-fermented green tea by M. pilosus on the content of glutathione (GSH) (A) and lipid peroxide (LPO) (B) in liver of mouse fed high fat diets for 7 weeks. Values are mean \pm standard deviation $(n=6)$, different superscripts on the bars indicate significant difference $(p<0.05)$.
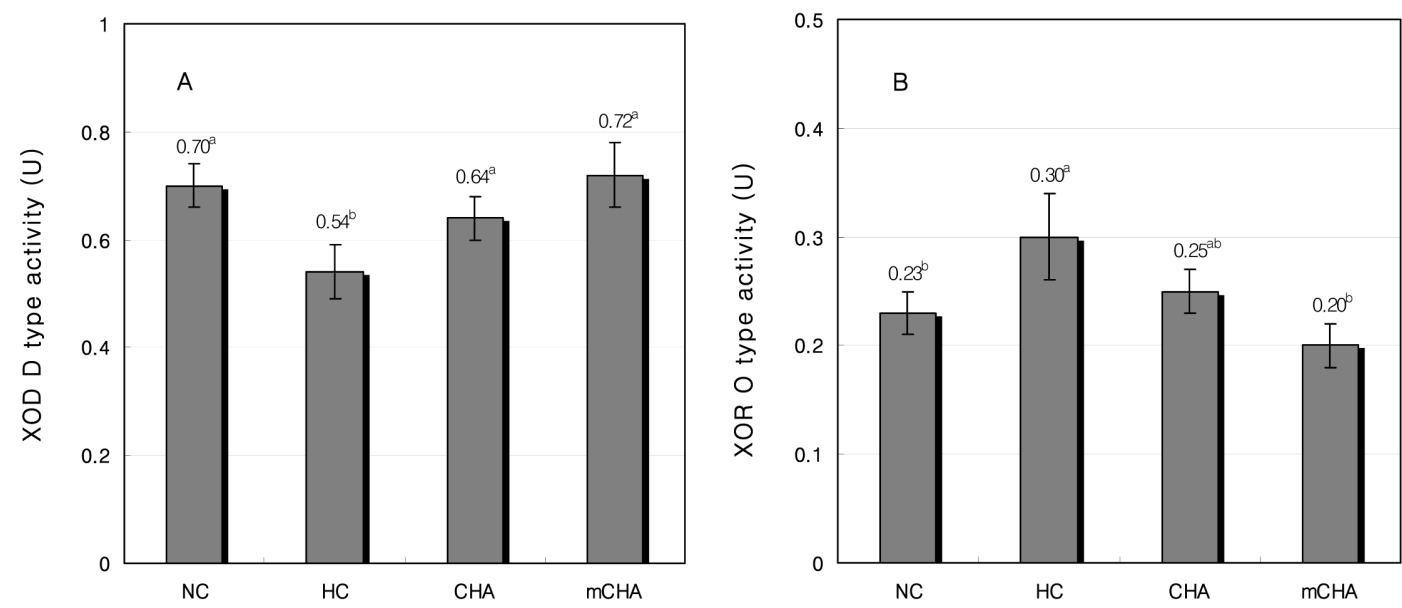

Fig. 3 Effects of unfermented and post-fermented green tea by M. pilosus the activities of hepatic XOR D (A) and O type (B) enzyme in the mouse fed high fat diets for 7 weeks. Units of XOR D type and O type activity are represented as uric acid nmole/min/mg protein, respectively. Values are mean $\pm \mathrm{SD}(\mathrm{n}=6)$, different superscripts on the bars indicate significant difference $(p<0.05)$.

pyrimidine, aldehyde류 및 heterocyclic 화합물의 대사에 관여하 는 비특이적인 효소(Park 등, 1997)로 정상적인 생리적 상태에 서는 $\mathrm{NAD}^{+}$를 전자수용체로 하는 dehydrogenase type (D type)으로 작용하나 조직이 손상되는 등의 병태적 생리상태(Oei 등, 1982; Urano 등, 1991; Ham와 $\operatorname{Kim} 2004)$ 에서는 분자상 의 $\mathrm{O}_{2}$ 를 전자수용체로 이용하는 oxidase type (O type)으로 작 용함으로서 ROS를 생성한다(Hashim 등, 2005).

따라서 상기의 결과는 $\mathrm{mCHA}$ 가 고지방식이로 활성화되는 XOR O type 효소의 활성을 억제하고 $\mathrm{D}$ type 효소의 활성을 높임으로서 ROS의 생성을 감소시키는 것으로 생각된다.

간 조직 ROS 소거계 효소활성과 혈청 ALT 활성. 7주간 사육 한 실험동물 간 조직의 $\mathrm{SOD}, \mathrm{GST}$ 및 $\mathrm{GPX}$ 활성과 $\mathrm{ALT}$ 활성 을 측정한 결과는 Fig. 5과 같다. $\mathrm{SOD}$ 활성(U/mg protein)은 $\mathrm{HC}$ 군에서보다 $\mathrm{CHA}$ 군과 $\mathrm{mCHA}$ 군에서 다소 높은 경향을 보였 으나 유의적인 차이는 없었다(Fig. $4 \mathrm{~A})$. 그러나 $\mathrm{mCHA}$ 군의 $\mathrm{GST}$ 활성(thioether $\mathrm{nmole} / \mathrm{min} / \mathrm{mg}$ protein)은 $\mathrm{HC}$ 군과 유의적인 차이를 나타내었으며(Fig. $4 \mathrm{~B}$ ) 특히, $\mathrm{mCHA}$ 군의 $\mathrm{GPX}$ 의 활성
(NADPH nmole/min/mg protein)은 $\mathrm{HC}$ 군의 2.55배, $\mathrm{CHA}$ 군의 1.5 배로 높았으며 $\mathrm{NC}$ 군과 대등하였다(Fig. $4 \mathrm{C}$ ). 한편, 간 손상 정도의 지표로 알려진 $\mathrm{ALT}$ 활성(Karment units)은 $\mathrm{CHA}$ 군과 $\mathrm{mCHA}$ 군에서 각각 29.90 및 22.10 으로 $\mathrm{NC}$ 군의 21.96과 유의 적인 차이를 보이지 않았으며 $\mathrm{HC}$ 군의 58.65 에 비하여 현저하 게 낮은 수치를 나타내었다(Fig. 4D).

XOR O type 효소에 의하여 생성되는 ROS는 체내에서 산화 적 스트레스를 동반함과 동시에 각종 질병유발에 관여하며 고 지방식이는 이 효소의 활성이 촉진된다(Fig. $3 \mathrm{~B}$ ). 그러나 생성 된 $\mathrm{ROS}$ 는 $\mathrm{SOD}, \mathrm{GST}, \mathrm{GPX}$ 및 catalase와 같은 소거계 효소 와 $\mathrm{GSH}$, vitamin $\mathrm{C}$ 및 $\mathrm{E}$ 등과 같은 물질들에 의하여 제거된 다(Flohe 등, 1973).

일반적으로 $\mathrm{SOD}$ 는 superoxide를 독성이 낮은 hydrogen peroxide $\left(\mathrm{H}_{2} \mathrm{O}_{2}\right)$ 로의 전환하며( $\mathrm{Im}$ 등, 1985), GPX는 hydrogen peroxide 뿐만 아니라 ROS에 의해 생성된 $\mathrm{LPO}$ 를 무독화 한다 (Jacoby, 1978). 한편, GST는 selenium 비의존성 항산화 효소로 친전자성 물질 등에 환원형 $\mathrm{GSH}$ 을 포접하여 glutathione 

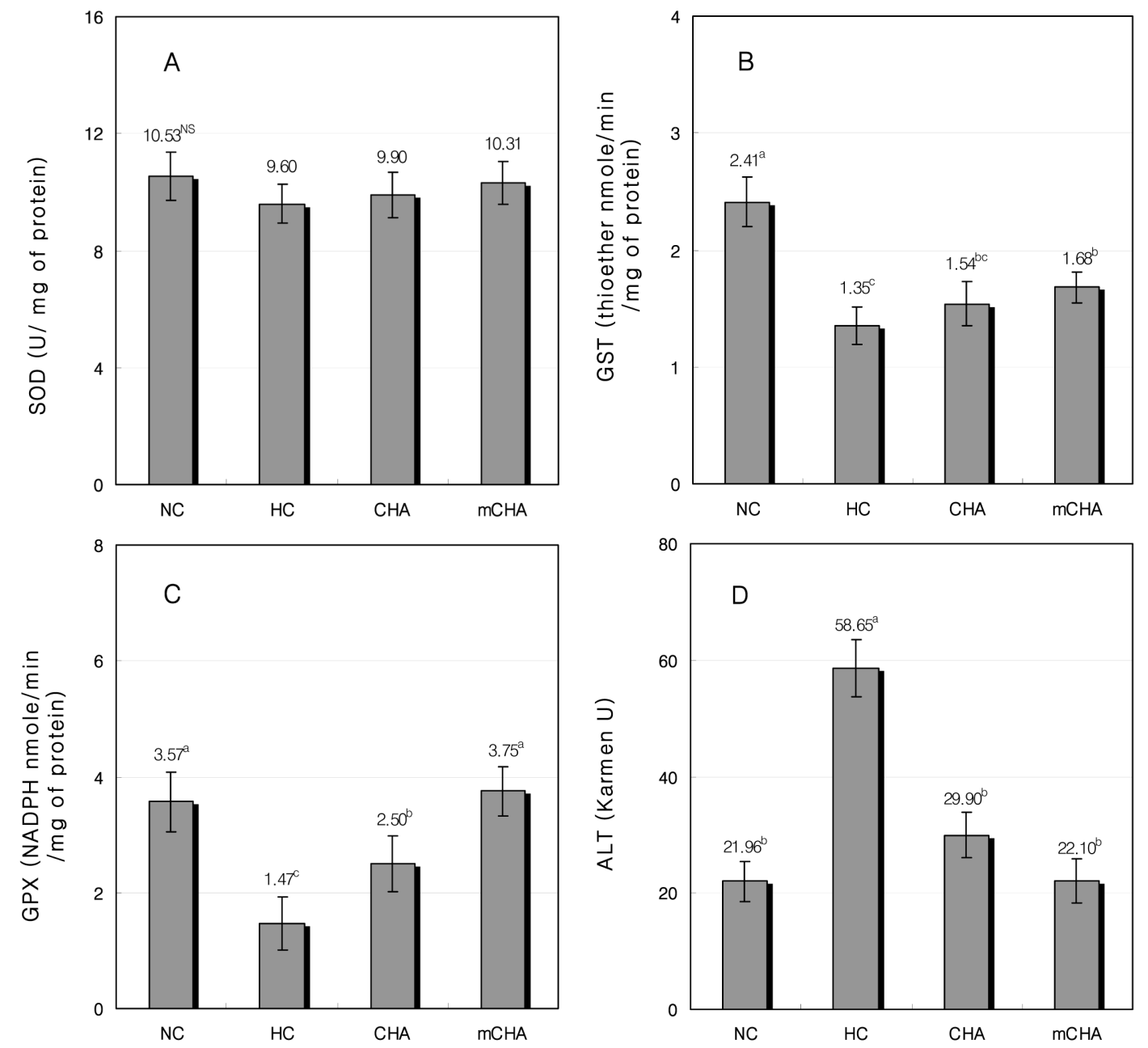

Fig. 4 Effects of unfermented and post-fermented green tea by M. pilosus on the activities of hepatic SOD (A), GST (B), GPX (C) and activity of serum ALT (D) in the mouse fed high fat diets for 7 weeks. Values are mean \pm SD $(n=6)$, different superscripts on the bars indicate significant difference $(p<0.05)$.

thioeter (R-S-G)를 생성하며 생성된 $\mathrm{GSH}$ 는 $\mathrm{LPO}$ 에 작용하여 독성이 낮은 lipid alcohol로 전환케 한다(Adams 등, 1983).

본 연구에서의 고지방식이는 항산화계 효소활성을 급격하게 감소시키며 LPO의 함량을 증가시킨다는 Lee 등(2010)과 Song 등(2010)의 연구결과 일치한다. 또한 ALT는 아미노기의 전이에 관여하는 효소로 간 조직이 손상되면 혈액으로 유출되어 혈청 에서 활성이 증가하며(Ham와 $\mathrm{Kim}, 2004)$, 고지방 식이는 간에 다양한 대사성 스트레스를 줌으로서 혈청 ALT의 활성이 증가 한다(Savransky 등, 2007). 녹차에 비하여 M. pilosus로 발효시 킨 후발효 녹차에서 비록 유의적인 차이는 없으나 ALT의 활성 이 낮은 것은 Zhang 등(1990)이 Monascus속 미생물을 번식시 킨 홍국이 bromobenzene으로 손상시킨 흰쥐의 간을 회복시킨 다는 결과와 일치한다.

따라서, 상기의 결과는 $\mathrm{CHA}$ 또는 $\mathrm{mCHA}$ 첨가 식이가 고지 방식이에서 생성되는 $\mathrm{ROS}$ 소거계 효소류의 활성을 증가시킴으 로서 간 조직의 산화적 손상을 예방하거나 감소시키며, 이러한 효과는 $\mathrm{mCHA}$ 가 $\mathrm{CHA}$ 에 비하여 높음을 나타낸다(Fig. 3과 4). 간 조직의 현미경 관찰. 7 주간 사육한 실험동물 간 조직을 검 경한 결과는 Fig. 7과 같다. $\mathrm{NC}$ 군은 정상적인 간 조직구조를
나타낸 반면 $\mathrm{HC}$ 군은 간 세포 내 포말형 지방과 매우 큰 소적 형 지방이 축적되어 있고, 세포괴사와 염증세포의 침윤현상( $\uparrow)$ 이 관찰되었다(Fig. 5의 $\mathrm{HC}$ ). $\mathrm{CHA}$ 군에서는 소적형 지방축적은 다소 감소되었으나 염증세포와 쿠퍼세포가 활성화된 모습이 보 이고, 중심정맥 주변부의 정상적인 간 실질세포는 매우 적은 양 상을 보인다(Fig. 5의 $\mathrm{CHA}$ ). 반면 $\mathrm{mCHA}$ 군은 $\mathrm{HC}$ 군과 비교해 볼 때 간 실질세포내 지방들은 아주 작은 포말형을 나타내며 정상적인 간 실질세포의 형태가 비교적 잘 나타나 고지방 식이 로 인한 간장 세포의 손상을 완화시킨 것으로 나타나고 있다 (Fig. 5의 mCHA). 따라서 고지방식이 대조군인 $\mathrm{HC}$ 군은 전형 적인 비알코올성 지방간 병변이 유도되었으며(Popper와 Schaffner, 1986), 조직 병리학적으로 관찰한 결과, 간장 세포질 내 수많은 소적형태의 지방이 축적되었으며(Grundmann와 Geller, 1992), 간장 소엽 내 세포판과 동양혈관 구조가 붕괴되 고 국소적인 염증세포의 침윤이 관찰되었다(Franke 등, 1979). 그러나 $\mathrm{CHA}$ 군과 $\mathrm{mCHA}$ 군에서는 간세포 내 축적된 지방의 크 기가 작은 포말형으로 변화되고, 이로 인해 간세포의 체적증가 가 있음에도 간 세포판과 동양혈관 형성이 간 소엽단위로 구분 되었으며, 중심정맥 주변으로 지방축적이 없는 정상적인 간 세 

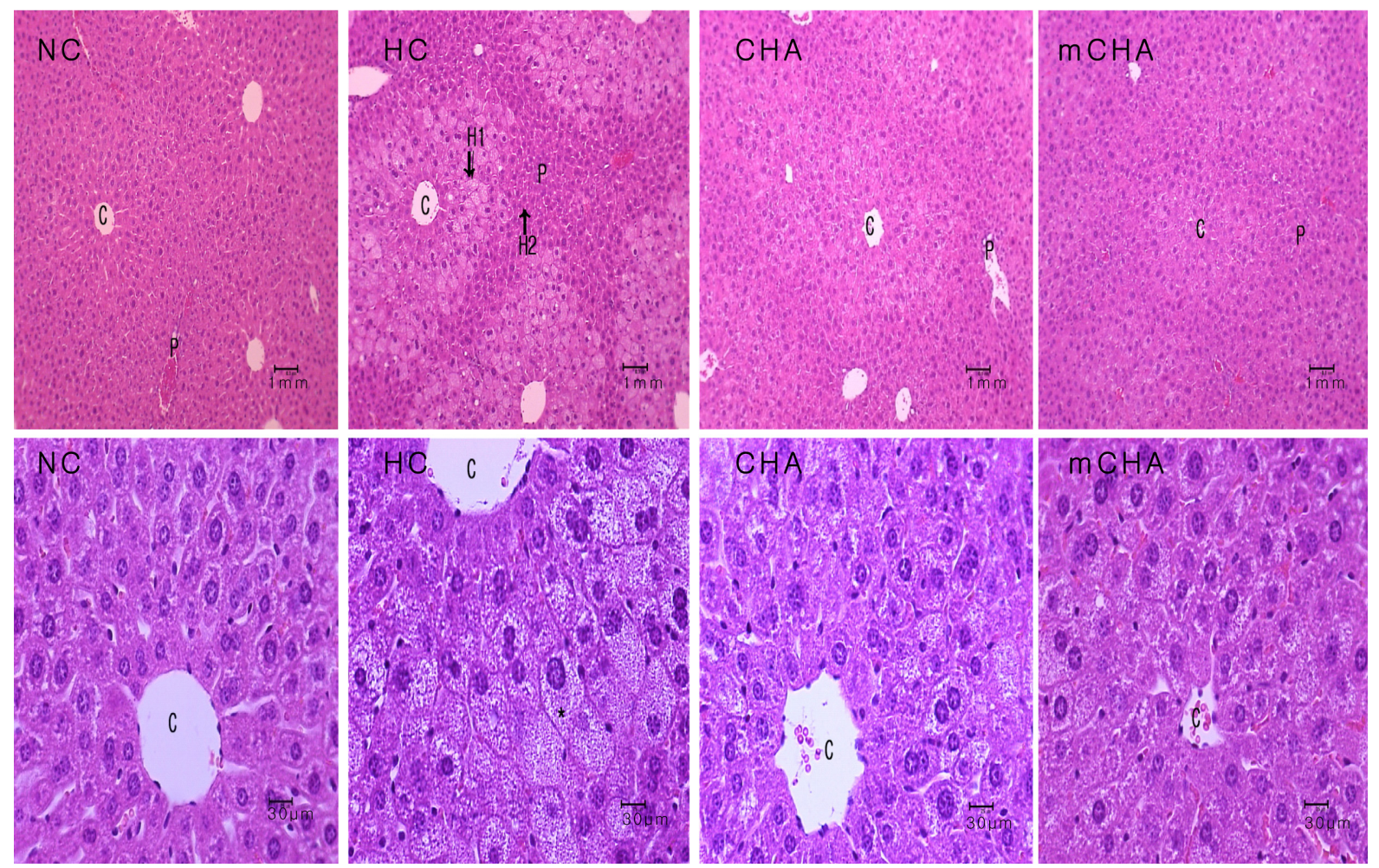

Fig. 5 Light microscopic photographs of liver tissue of mouse fed unfermented and post-fermented green tea by M. pilosus supplemented high fat diets for 7 weeks (HE stain). Abbreviations: See Table 1. C; central vein. P; portal vein. Arrow (H1); focal infiltration of inflammatory cells. Arrow (H2); hepatocytes of central vein.

포영역이 증가되는 것으로 나타났으며 이러한 현상은 $\mathrm{CHA}$ 군 에 비하여 $\mathrm{mCHA}$ 군에서 뚜렷하였다.

\section{초 록}

Monascus pilosus로 발효시킨 후 발효 녹차의 첨가식이가 고지 방식이 ICR 마우스의 체중과 혈청 지방함량 및 간 조직 항산 화계 효소활성에 미치는 영향을 조사하였다. 정상대조군 $(\mathrm{NC})$, 고지방식이대조군 $(\mathrm{HC})$, 비발효녹차 분말을 $2 \%$ 첨가한 고지방 식이군(CHA) 및 M. pilosus로 발효시킨 후발효녹차 분말을 $2 \%$ 첨가한 고지방식이군 $(\mathrm{mCHA})$ 으로 구분하여 7주간 사육하였다. 체중은 $\mathrm{CHA}$ 군과 $\mathrm{mCHA}$ 군간의 유의적인 차이가 없으나 $\mathrm{HC}$ 군 에 비하여 각각 24.15 및 $29.66 \%$ 가 감소되었으며 식이섭취량 에는 차이가 없었다. 체중 당 간 및 신장의 중량은 $\mathrm{CHA}$ 군 및 $\mathrm{mCHA}$ 군이 $\mathrm{HC}$ 군에 비해 증가하였다. 체중 당 부고환주위지방 의 무게는 $\mathrm{mCHA}$ 군에서 유의하게 감소하였다. 혈청 $\mathrm{TG}$ 와 의 총콜레스테롤 함량은 $\mathrm{mCHA}$ 군에서 $\mathrm{NC}$ 군 수준으로 감소하였 다. $\mathrm{CHA}$ 군과 $\mathrm{mCHA}$ 군의 $\mathrm{HDL}$-cholesterol 함량은 $\mathrm{HC}$ 군에 비 하여 96.55 및 $119.32 \%$ 가 높았다. $\mathrm{CHA}$ 군과 $\mathrm{mCHA}$ 군의 $\mathrm{CHA}$ 군 및 $\mathrm{mCHA}$ 군의 $\mathrm{LDL}-\mathrm{cholesterol} \mathrm{함량은} \mathrm{각각} 0.67$ 및 0.41 을 나타내었다. 간 조직의 $\mathrm{GSH}$ 함량은 $\mathrm{HC}$ 군에 비하여 $\mathrm{CHA}$ 군이 $11.24 \%, \mathrm{mCHA}$ 군은 $23.68 \%$ 가 높았다. $\mathrm{LPO}$ 함량은 $\mathrm{CHA}$ 군과 $\mathrm{mCHA}$ 군이 $\mathrm{HC}$ 군에 비하여 43.70 및 $45.38 \%$ 가 낮 았다. $\mathrm{CHA}$ 군과 $\mathrm{mCHA}$ 군의 xanthine oxidoreductase $\mathrm{D}$ type 효소활성은 $\mathrm{HC}$ 군에 비하여 각각 18.52 및 $33.33 \%$ 가 감소하였
으며 $\mathrm{mCHA}$ 군은 $\mathrm{NC}$ 군 수준으로 높았다. $\mathrm{XOD} \mathrm{O}$ type 효소활 성은 $\mathrm{CHA}$ 군과 $\mathrm{mCHA}$ 군이 $\mathrm{HC}$ 군에 비하여 각각 16.67 및 $33.33 \%$ 가 높았다. superoxide dismutase 활성은 $\mathrm{CHA}$ 군과 $\mathrm{mCHA}$ 군이 $\mathrm{HC}$ 군에 비하여 유의차는 없었다. $\mathrm{mCHA}$ 군의 glutathione S-transferase 활성은 $\mathrm{HC}$ 군에 비하여 유의적으로 높 았으며 특히, $\mathrm{mCHA}$ 군의 glutathione peroxidase 활성은 $\mathrm{HC}$ 군 의 2.55 배, $\mathrm{CHA}$ 군의 1.5 배로 높았으며 $\mathrm{NC}$ 군과 대등하였다. $\mathrm{CHA}$ 군과 $\mathrm{mCHA}$ 군의 $\mathrm{ALT}$ 활성 $\mathrm{HC}$ 군에 비하여 현저하게 낮 았다. 간 조직의 현미경 관찰결과, $\mathrm{CHA}$ 군과 $\mathrm{mCHA}$ 군에서는 간 세포 내 축적된 지방의 크기가 작은 포말형으로 변화되고, 이 로 인해 간 세포판과 동양혈관 형성이 간 소엽단위로 뚜렷하게 구분되었다.

이상의 실험결과로 보아 M. pilosus로 발효시킨 후발효 녹차 는 고지방식이에 의해 유발되는 비만과 고지혈증 및 지방간을 예방 혹은 경감시켜줄 수 있는 유효한 가능성을 시사하였다.

Keywords antiobese ' anti-fatty liver - antioxidative enzymes · hypolipidemic $\cdot$ Monascus pilosus $\cdot$ post-fermented tea

감사의 글 본 연구는 농촌진흥청 차세대 바이오그린21사업(과제번호: PJ0080932011)과 농림수산식품부 농림바이오기술산업화지원사업(81000703-1-SU000)에 의해 수행되었습니다.

\section{참고문헌}

Adams JD, Lauerberg BH, and Mitchell JR (1983) Plasma glutathione and 
glutathione disulfide in rat: Regulation and response to oxidative stress. $J$ Pharmacol Exp Ther 227, 749-54.

Arad Y, Ramakrishnan R, and Ginsberg HN (1990) Lovastatin therapy reduces low density lipoprotein apoB levels in subjects with combined hyperlipidemia by reducing the production of apoB-containing lipoproteins: Implications for the pathophysiology of apoB production. $J$ Lipid Res 31, 567-82.

Birch AJ, Cassera A, Fitton D, Holker JSE, Smith H, Tompson GA et al. (1962) Studies in relation to biosynthesis. Rotiorin, monascin and rubropunctatin. J Chem Soc 11, 3583-7.

Bode AM and Dong Z (2003) Signal transduction pathwasy: Targets for green and black tea. J Biochem Mol Biol 36, 66-77.

Chen YC, Liang YC, Lin-Shiau SY, Ho CT, and Lin JK (1999) Inhibition of TPA-induced protein kinase $\mathrm{C}$ and transcription activator protein-1 binding activities by theaflavin-3-3'-digallate from black tea in NIH3T3 cells. J Agric Food Chem 47, 1416-21.

Ellman GL (1959) Tissue sulfhydryl group. Arch Biochem Biophys 82, 70-7.

Endo A (1980) Monacolin-K, a new hypocholesterolemic agent that specifically inhibits 3-hydroxy-3-methylglutaryl coenzyme A reductase. $J$ Antibiotics 33, 334-6.

Feng Q, Torii Y, Uchida K, Nakamura Y, Hara Y, and Osawa T (2002) Black tea polyphenols, theaflavins, prevent cellular DNA damage by inhibiting oxidative stress and suppressing cytochrome P450 IAI in cell culture. $J$ Agric Food Chem 50, 213-20.

Flohe L, Gunzler WA, and Schock HH (1973) Glutathione peroxidase: A selenoenzyme. FEBS Lett 32, 132-4.

Franke WW, Denk H, Schmid E, Osborn M, and Weber K (1979) Ultrastructural, biochemical and immunological characterization of Mallory bodies in livers of griseofulvin-treated mice: Fimbriated rods of filaments containing prekeratin-like polypeptides. Lab Invest 40, 207-20.

Friedewald WT, Levy RI, and Fredrickson DS (1972) Estimation of the concentration of low-density lipoprotein cholesterol in plasma, without use of the preparative ultracentrifuge. Clin Chem 18, 499-502.

Gordon T, Kannel WB, Castelli WP, Thomase R, and Dawber TR (1981) Lipoproteins, cardiovascular disease, and death: The famingham study. Arch Intern Med 141, 1128-31.

Grundmann E and Geller SA (1992) In Histopathology: Color Atlas of Organs and Systems, p. 105, Urban and Schwarzenberg, USA.

Habig WH, Pabist MJ, and Jakoby WB (1974) Glutathione S-transferase. The first enzymatic step in mercapturic acid formation. $J$ Biol Chem 249, $7130-9$.

Ham YK and Kim SW (2004) Protective effects of plant extract on the hepatocytes of rat treated with carbon tetrachloride. J Korean Soc Food Sci Nutr 33, 1246-51.

Han SK, Song YS, Lee JS, Bang JK, Suh SJ, Choi JY et al. (2010) Changes of the chemical constituents and antioxidant activity during microbialfermented tea (Camellia sinensis L.) processing. Korean J Food Sci Technol 42, 21-6.

Hashim MS, Lincy S, Remya V, Teena M, and Anila L (2005) Effect of polyphenolic compounds from Coriandrum sativum on $\mathrm{H}_{2} \mathrm{O}_{2}$-induced oxidative stress in human lymphocytes. Food Chem 92, 653-60.

Ha SK and Chae C (2010) Inducible nitric oxide distribution in the fatty liver of a mouse with high fat diet-induced obesity. Exp Anim 59, 595-604.

Heber D, Yip I, Ashley JM, Elashoff DA, Elashoff RM, Liang V et al. (1999) Cholesterol-lowering effects of a proprietary Chinese red-yeast-rice dietary supplement. Am J Clim Nutr 69, 231-6.

Im MJ, Manson PN, Bulkley GB, and Hoopes JE (1985) Effects of superoxide dismutase and allopurinol in survival of acute island skin flaps. Ann Surgery 201, 357-9.

Jacoby JB (1978) The glutathione S-transferase. A group of multifunctional detoxification proteins. Adv Enzymol Relat Areas Mol Biol 46, 383-414.

Kang MH, Lee JH, Lee JS, Kim JH, and Chung HK (2004) Effect of acorn supplementation on lipid profiles and antioxidant enzyme activities in high fat diet-induced obese rats. Korean Nutr Soc 37, 169-75.

Kim DY (1989) The status and prospect of Korean green tea. Food Sci Ind 22, 2-12.

Lee IS, Lee SW, and Lee IZ (2003) Effects of tissue cultured ginseng on blood glucose and lipid in streptozotocin-induced diabetic rats. Korean $J$
Food Sci Technol 35, 280-5.

Lee J, Jeong JY, Cho YS, Park SK, Kim KJ, Kim MJ et al. (2010) Effect of young Phragmites communis leaves powder on lipid metabolism and erythrocyte antioxidant enzyme activities in high-fat diet fed mice. $J$ Korean Soc Food Sci Nutr 39, 677-83.

Lee JM, Cho WK, and Park HJ (1998) Effect of chitosan treated with enzymatic methods on glucose and lipid metabolism in rats. Korean $J$ Nutr 31, 312-8.

Lee SI, Kim JW, Lee YK, Yang SH, Lee IA, Suh JW et al. (2011a) Antiobesity effect of Monascus pilosus mycelial extract in high fat diet induced obese rats. Appl Biol Chem 54, 197-205.

Lee SI, Kim JW, Lee YK, Yang SH, Lee IA, Suh JW et al. (2011b) Protective effect of Monascus pilosus mycelial extract on hepatic damage in highfat diet induced-obese rats. $J$ Appl Biol Chem 54, 206-13.

Lee SU (1984) In History of Korean Foods, p. 240. Gyomunsa, Korea.

Liang YC, Chen YC, Lin YL, Lin-Shiau SY, Ho CT, and Lin JK (1999) Suppression of extracellular signals and cell proliferation by the black tea polyphenol, theaflavin-3,3'-digallate. Carcinogenesis 20, 733-6.

Lin YL, Tsai SH, Lin-Shiau SY, Ho CT, and Lin JK (1999) Theaflavin- 3,3'digallate from black teea blocks the nitric oxide synthase by downregulating the activation of nf-kappab in macrophages. Eur J Pharmacol 367, 379-88.

Lowry OH, Rosebrough NJ, Farr AL, and Randall RL (1951) Protein measurement by folin phenol reagent. $J$ Biol Chem 193, 265-75.

Martin JP, Dailey JM, and Sugarmanand E (1987) Negative and positive assays of superoxide dismutase based on hematoxylin autoxidation. Arch Biochem Biophys 255, 329-36.

Matsuzawa-Nagata N, Takamura T, Ando H, Nakamura S, Kurita S, Misu H et al. (2008) Increased oxidative stress precedes the onset of high-fat diet-induced insulin resistance and obesity. Metabolism 57, 1071-7.

Oei HH, Kentroo WE, Burton KP, and Schaffer SW (1982) A possible role of xanthine oxidase in pproducing oxidative stress in the heart of chronically ethanol treated rats. Res Commun Chem Pathol Pharmacol 38, 453-61.

Ohkawa H, Ohishi N, and Yagi K (1979) Assay for lipid peroxides in animal tissues by thiobarbituric acid reaction. Anal Biochem 95, 248-54.

Pagila ED and Valentine WN (1967) Studies on the quantitative and qualitative characterization of erythrocyte glutathione peroxidase. $J$ Lab Clin Med 70, 158-69.

Park BH, Beck KY, Lee SI, and Kim SD (2006) Effect of chitosan-ascorbate containing soyfiber beni-koji on body weight and lipd content of obesity rats aid induced from high fat diet. $J$ East Asian Soc Dietary Life 16, 663-9.

Park GY, Lee SJ, and Lim JG (1997) Effects of green tea catechin on cytochrome p450, xanthine oxidase activities in liver and liver damage in streptozveocin induced diabetic rats. J Korean Soc Food Sci Nutr 26, 901-7.

Popper H and Schaffner F (1992) In Progress in Liver Disease: Nonalcoholic Fatty Liver Disease, Schaffner F and Thaler H (eds.), vol. 8, pp. 283-98, Grune \& Stratton, USA.

Pyo YH and Lee TC (2007) The potential antioxidant capacity and angiotensin I-converting enzyme inhibitory activity of Monascusfermented soybean extracts as multifunctional food additives. J Food Sci 72, 218-23.

Reitman S and Frankel S (1957) A colorimetric method for thedetermination of serum glutamic oxalacetic and glutamic pyruvic transaminases. $\mathrm{Am} \mathrm{J}$ Clin Pathol 28, 56-63.

Savransky V, Bevans S, Nanayakkara A, Li J, Smith PL, Torbenson MS et al. (2007) Chronic intermittent hypoxia causes hepatitis in a mouse model of diet-induced fatty liver. Am J Physiol Gastrointest Liver Physiol 293, 871-7.

Song WY, Sung BH, Kang SK, and Choi JH (2010) Effect of water extracts from Phellinus linteus on lipid composition and antioxidative system in rats fed high fat high cholesterol diet. J Korean Soc Food Sci Nutr 39, $71-7$.

Stripe F and Della Corte E (1969) The regulation of rat liver xanthine oxidase. $J$ Biol Chem 244, 3855-60.

Trevisanato SI and Kim YI (2000) Tea and health. Nutr Rev 58, 1-10. 
Urano S, Midori H, Tochihi N, Matsuo M, Shiraki M, and Ito H (1991) Vitamin $\mathrm{E}$ and the susceptibility of erythrocytes and reconstituted liposome to oxidative stress in aged diabetics. Lipids 26, 58-62.

Vladislav E, Dana K, and Monika B (2004) The effect of curcumin on cadmium-induced oxidative damage and trace elements level in the liver of rats and mice. Toxicology Lett 151, 79-85.

Wang RS, Nakajima T, and Honma T (2000) Different change patterns of the isozymes of cytochrome P450 and glutathione $S$-ttterferase in chemically induced liver damage in rat. Ind Health 37, 440-8.

Wilson JN, Wilson SP, and Eator RP (1984) Dietary fiber and lipoprotein metabolism in the genetically obese Zucker rat. Arteriosclerosis 4, 147-
53

Wu YG, Xia LL, Lin H, Zhou D, Qian H, and Lin ST (2007) Prevention of early liver injury by breviscapine in streptozotocin-induced diabetic rats. Planta Med 73, 433-8.

Yang CS, Jung JY, Yang G, Chhabra SK, and Lee MJ (2000) Tea and tea polyphenols in cancer prevention. $J$ Nutr 130, 472S-8S.

Yu MH, Lee HH, Im HG, Hwang Bo MH, Kim JH, and Lee IS (2005) The effects of kimchi with Monascus purpureus on the body weight gain and lipd metabolism in rats fed high fat diet. Life Sci 15, 536-41.

Zhang ZL, Wen QZ, and Liu CX (1990) Hepatoprotective effects of Astraglus root. J Ethnopharmacol 30, 145-9. 